\title{
The challenge of developmental therapeutics for adrenocortical carcinoma
}

\author{
Ricardo Costa ${ }^{1,2}$, Benedito A. Carneiro, ${ }^{1,2}$, Fabio Tavora ${ }^{4}$, Sachin G. Pai, ${ }^{1,2}$, Jason \\ B. Kaplan ${ }^{1,2}$, Young Kwang Chae ${ }^{1,2}$, Sunandana Chandra ${ }^{1,2}$, Peter A. Kopp ${ }^{3}$ and \\ Francis J. Giles ${ }^{1,2}$ \\ ${ }^{1}$ Northwestern Medicine Developmental Therapeutics Institute, Robert H. Lurie Comprehensive Cancer Center of Northwestern \\ University, Chicago, IL, USA \\ ${ }^{2}$ Division of Hematology and Oncology, Feinberg School of Medicine, Northwestern University, Chicago, IL, USA \\ ${ }^{3}$ Division of Endocrinology, Metabolism, and Molecular Medicine, Feinberg School of Medicine, Northwestern University, \\ Chicago, IL, USA \\ ${ }^{4}$ Department of Pathology, Messejana Heart and Lung Hospital, Fortaleza, Brazil \\ Correspondence to: Ricardo Costa, email: ricardo.costa@northwestern.edu \\ Keywords: adrenocortical carcinoma, targeted therapy, IGF-1R, $\beta$-catenin, VEGFR \\ Received: March 02, $2016 \quad$ Accepted: April 10, $2016 \quad$ Published: April 18, 2016
}

\section{ABSTRACT}

Adrenocortical carcinoma (ACC) is a rare disease with an estimated incidence of only 0.7 new cases per million per year. Approximately $30-70 \%$ of the patients present with advanced disease with very poor prognosis and without effective therapeutic options. In the recent years, unprecedented progresses in cancer biology and genomics have fostered the development of numerous targeted therapies for various malignancies. Immunotherapy has also transformed the treatment landscape of malignancies such as melanoma, among others. However, these advances have not brought meaningful benefits for patients with ACC. Extensive genomic analyses of ACC have revealed numerous signal transduction pathway aberrations (e.g., insulin growth factor receptor and $\mathrm{Wnt} / \beta$-catenin pathways) that play a central role in pathophysiology. These molecular alterations have been explored as potential therapeutic targets for drug development. This manuscript summarizes recent discoveries in ACC biology, reviews the results of early clinical studies with targeted therapies, and provides the rationale for emerging treatment strategies such as immunotherapy.

\section{INTRODUCTION}

Adrenocortical carcinoma (ACC) is an exceedingly rare malignancy with no effective standard treatment options. ACC is responsible for $0.2 \%$ of all cancer deaths in the United States and has an estimated incidence of 0.7 cases per million per year.[1] The disease incidence has a bimodal distribution with peaks in the first and fourth decades of life, and a female to male ratio 1.52.5:1.[2,3] A growing number of patients are noted to have asymptomatic, indolent adrenal incidentalomas after undergoing abdominal imaging; in this patient population, the estimated incidence of ACC is as high as
5\%.[4-7] The pathologic diagnosis of ACC is based on multiple morphologic parameters that are suggestive but not pathognomonic of malignancy.[8-10] The most widely used diagnostic score are known as Weiss criteria, with several updates, and includes the following parameters: mitosis, atypical mitosis, necrosis, venous invasion, sinusal invasion, capsular invasion, nuclear atypia, diffuse architecture, and clear cell change.[8, 9] Molecular analyses have been recently attempted in helping diagnosis, in particular hypermethylation, miRNA, TP53, $Z N R F 3, \beta$-catenin are possible candidates that could help diagnose and establish prognosis, but are not yet used in current pathologic diagnosis.[11] About 40-60\% of patients with malignant tumors of the adrenal glands 
present with symptoms related to excessive hormonal production such as hypercortisolism or hyperandrogenism. $[2,12]$

Most cases of ACC are sporadic with no identifiable risk factor. Rarely, ACC can be part of tumor hereditary syndromes associated with specific germ line mutations, namely Li-Fraumeni (TP53 gene mutation) or Lynch syndrome (mutations in various mismatch repair genes). [13-15] Case reports have also suggested an increased risk of ACC in multiple endocrine neoplasia syndrome type 1 (MEN1) and familial adenomatous polyposis.[16] Surgery is the treatment of choice for patients presenting with resectable disease and is often followed by adjuvant chemotherapy with mitotane to mitigate the risk of disease recurrence in high-risk patients despite the lack of prospective data to support this approach.[17] The group of approximately $30-70 \%$ of patients presenting with unresectable metastatic disease carry an extremely poor prognosis related to the aggressive biological behavior and the lack of effective therapeutic options.[2, 12] Mitotane, which contains cytotoxic and anti-steroid synthesis activity properties, has been the corner stone of the treatment of advanced disease for decades.[18, 19] Limited benefit from polychemotherapy contributes to the dismal prognosis of advanced disease with an estimated 5 -year survival rate of less than 15\%.[20]

Major advances in the understanding of the genetic pathophysiology of cancer have led to significant advancement in the treatment of several malignancies including the development of effective targeted therapies.[21] Investigation of the genomic landscape of ACC revealed that it is a biologically and genetically heterogeneous malignancy with transcriptome clusters associated with distinct clinical behaviors.[11] These studies also demonstrated potential therapeutic targets that will be reviewed in this manuscript.

\section{CURRENT TREATMENT APPROACH}

Mitotane, the only FDA-approved drug for ACC, displays single-agent activity (10-30\% tumor response rates) based on its adrenolytic activity but its broad clinical use is challenged by an unfavorable toxicity profile.[2224] The published trials on mitotane monotherapy activity are for the most part retrospective. Only two prospective trials have been reported with less than 20 patients each with no clear survival benefit.[25, 26] Polychemotherapy has also limited efficacy in advanced disease with smalluncontrolled studies showing response rates of $10-33 \%$. [27-29]

There have been a few studies of potential biomarkers to help identify patients who may benefit from mitotane and/or platinum-based chemotherapy. In the adjuvant setting, establishing the tumor proliferation index by Ki-67 labeling, with a cutoff of $10 \%$ dividing two groups of patients with high and low risk, may help in the decision to use mitotane alone or in combination with other drugs.[30-32] A few studies have also addressed the expression of ribonucleotide reductase large subunit and excision repair cross-complementation group 1 (ERCC1) in ACC at the protein level by immunohistochemistry, and determined the association of the expression with clinical outcome and response to mitotane and cytotoxic therapy, but the results are inconsistent.[33-35]

The only chemotherapy based phase III randomized clinical trial ever conducted in advanced ACC showed that mitotane combined with etoposide, doxorubicin and cisplatin (EDPM) provided additional clinical benefit compared to mitotane plus streptozocin.[36] The patients randomized to receive EDPM had higher tumor response rates when compared to patients treated with streptozocin combined with mitotane (23\% vs. 9\%). Prolongation of progression-free survival (PFS) was also observed in the EDPM arm (5 vs. 2 months). There was no significant benefit in overall survival (OS) (14 vs. 12 months). It is important to emphasize that up to $58 \%$ of patients receiving EDPM had serious adverse events compared to $41 \%$ in the mitotane plus streptozocin arm.

The cytotoxic mechanism of action as well as resistance mechanisms to mitotane are not well understood.[24] Mitotane is also generally not well tolerated as monotherapy and levels $>14 \mathrm{mcg} / \mathrm{ml}$ are associated with better antitumor response.[37] It is important to review that mitotane is a strong cytochrome P450-3A4 (CYP3A4) inducer and this may lead to significant drug interactions and decrease the activity of combination strategies.

The results of the FIRM-ACT phase III trial showing modest improvement of disease control with polychemotherapy and the high frequency of serious adverse events stresses the pressing need for more effective therapies. Furthermore in light of the rate of serious adverse events there is no clear evidence that a combination of cytotoxic agents with mitotane is better than a sequential strategy.

\section{POTENTIAL THERAPEUTIC TARGETS}

\section{Insulin growth factor (IGF)/mTOR signaling}

Insulin growth factor receptor 1 (IGF-1R) is a transmembrane cellular receptor which has a heterotetrameric structure, characterized by two 'half receptors', each of which in turn comprises a predominately extracellular $\alpha$-chain that is involved in ligand binding and a predominately intracellular $\beta$-chain that includes the tyrosine kinase domain.[38]

Activation of the IGF-1R by one of its ligands insulin-like growth factor 2 (IGF2), encoded by a gene that is located among a gene cluster on chromosome $11 \mathrm{p} 15$ and 
that undergoes genomic imprinting, results in activation of the PI3K/AKT/mTOR cascade and the RAS-MAPK pathway leading to stimulation of protein translation and cell proliferation (Figure 1).[39]

Chromosome $11 \mathrm{p} 15$ abnormalities are present in up to $90 \%$ of sporadic ACCs and IGF2 is commonly overexpressed in this tumor.[40] In fact both IGF2 mRNA and protein are overexpressed in more than $90 \%$ of ACC, with a good correlation between mRNA and protein.[41] Mounting evidence suggest that overproduction of IGF2 is due to uniparental disomy or loss of imprinting of the maternal allele.[42, 43] Moreover, IGF2 is expressed differently in ACC when compared adrenocortical adenomas or normal adrenal cortex tissue.[44] It has been hypothesized that IGF2 overexpression is low or absent in the beginning of oncogenesis, which may suggest that other signaling pathways may also play a role in the ACC tumorigenesis.[43]

Evidence also suggests that the IGF-1R plays a pivotal role in ACC pathophysiology representing an important therapeutic target in advanced ACC.[43, 45] Indeed, the $I G F 2$ gene and protein expression has been associated with aggressive clinic-pathological features of ACC when assessed by immunohistochemistry and gene expression arrays (i.e., high grade and metastatic disease).[44, 46] These results provided the rationale and fostered the clinical development of anti-IGF antibodies for treatment of this disease.

Linsitinib, an oral small molecule inhibitor of both the IGF-1R and the insulin receptor, generated significant enthusiasm based on early clinical results. In a phase I trial, 14 patients with refractory ACC were treated with 3 intermittent dosing schedules of linsitinib.[47] Two out of the 9 patients had partial responses and remained in the study for 703 and 199 days, respectively. A doubleblind, placebo-controlled phase III clinical trial evaluated the efficacy of linsitinib in 139 previously treated patients with advanced ACC.[48] The study was prematurely stopped due to the failure of linsitinib to improve PFS or OS compared to placebo (median OS: 323 vs. 356 days; HR 0.94; $p=0.77$ ).

Of note $90 \%$ of patients in the linsitinib arm had been exposed to mitotane based chemotherapy in the metastatic setting. A short mitotane wash out period could have affected linsitinib efficacy due interaction through CYP3A4.[49] Also despite reported equivalent levels of IGF-1 in active linsitinib and placebo groups question remains if linsitinib reached its target. Finally, IGF-1R might not be a major driver of adrenocortical carcinoma. Overexpression of IGF-2 could represent a bystander

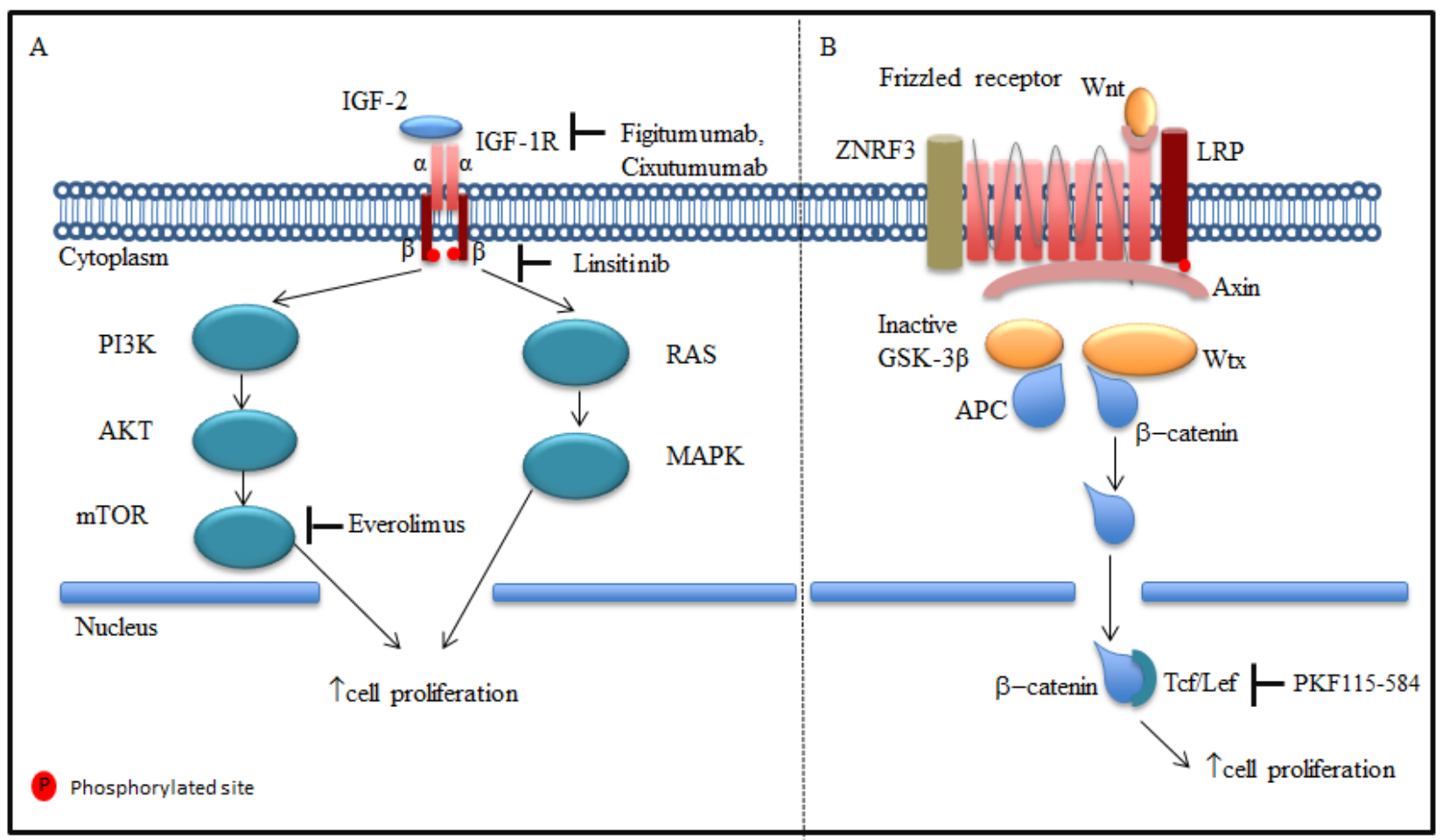

Figure 1: IGF-1R and Wnt/Frizzled receptor pathways. A. In adrenocortical carcinoma cells IGF2 binds to IGF1 receptor (IGF1R) family. IGF-1R has a tetrameric structure in which the intra-cellular $\beta$-chain tyrosine kinase activity regulated by ligand binding to extra-cellular $\alpha$ chain. Downstream of these receptors are the well-known Akt and MAPK intracellular signaling networks, which when activated promote cell proliferation. B. The Wnt proteins, by binding to frizzled receptors and the LRP co-receptor, act to suppress the

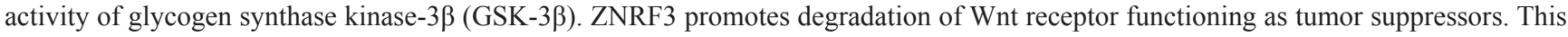
prevents phosphorylation of downstream molecules allowing $\beta$-catenin association with Tcf/Lef in the nucleus and subsequent increased cell proliferation. 
effect caused by dysregulation of another gene at $11 \mathrm{p} 15$, including, p57Kip 2 or other transcripts at the loci.[50, 51] Finally, ACC could be driven by multiple pathway aberrations requiring combination targeted therapies as discussed below.

Figitumumab, a fully human $\operatorname{IgG} 2$ monoclonal antibody that targets the IGF-1R, was tested in a phase I dose-escalation study in patients with advanced solid tumors. $[52,53]$ After a total of 50 cycles of figitumumab administered, no responses were documented among the 14 patients with previous treated metastatic ACC and no patients had stable disease lasting more than 6 months. Cixutumumab (IMC-A12), another antibody with high affinity to IGF-1R, was evaluated in combination with mitotane as first-line treatment among 20 patients with metastatic ACC. A partial response was observed in one patient $(5 \%)$ and the trial was terminated due to slow accrual and low response rates. The most common toxicities mirrored the ones commonly seen with mitotane alone, namely diarrhea and neurological complications. [54] Cixutumumab was also tested in combination with the mTOR inhibitor temsirolimus for the treatment of 42 patients with advanced solid tumors in a phase I trial. Four out of 10 patients with ACC had stable disease lasting longer than 8 months, prompting the opening of an ACC expansion cohort that included 26 patients. [55] There were no partial or complete responses, but $42 \%$ achieved stable disease for at least 6 months. The combination was relatively well tolerated with toxicities known to be associated with temsirolimus including mucositis, thrombocytopenia, hypertrygliceridemia, hypercholesterolemia, and hyperglycemia.[56]

These results highlight the therapeutic potential of combinatorial strategies and the possible role of mTOR inhibitors. In fact, De Martino et al. recently evaluated the expression of mTOR and downstream molecules in ACC and showed activation of the pathway in a subset of tumors.[57] Nevertheless, single-agent everolimus, another mTOR inhibitor, showed no signal of clinical activity in an exploratory study of 4 patients with advanced ACC.[58]

\section{Vascular endothelial growth factor receptor pathway}

The family of vascular endothelial growth factor receptors (VEGFRs) plays a central role in tumor angiogenesis. Of the three VEGFRs, VEGFR1 (fms-like tyrosine kinase-1), VEGFR2 (fetal liver kinase-1/kinase insert domain receptor), and VEGFR3 (fms-like tyrosine kinase-4), VEGFR2 has the most significant role in mediating the growth of blood vessels necessary for tumor growth.[59] Activation of the VEGFR pathway has been well documented in ACC and provides the rationale for targeting these receptors.[60, 61]
Axitinib (AG-013736) is an oral, potent, and selective oral inhibitor of VEGFR tyrosine kinases 1, 2, 3.[62] In phase II study, axitinib administered to 13 patients with metastatic or locally advanced ACC resulted in no responses.[63] Sorafenib, an inhibitor of several tyrosine kinase receptors such as VEGFR2, VEGFR3, platelet-derived growth factor receptor (PDGFR), and RAF-1, was investigated in a phase II trial in combination with paclitaxel for patients with advanced disease and showed no clinical activity. [64] [65] Sunitinib, another multikinase inhibitor with activity against VEGFR and PDGFR, was also investigated in a phase II trial with 35 patients with refractory ACC.[66] There were no documented tumor responses and the median PFS was 2.8 months.[67] However sunitinib serum levels might have been reduced by mitotane induced CYP3A4 activity attenuating its antitumor activity and adverse effects.

Lastly, bevacizumab, an anti-VEGF antibody, was given in combination with capecitabine to 10 patients with locally advanced or metastatic disease after treatment with mitotane and at least one line of chemotherapy led to no meaningful clinical benefit was observed.[68] These results document the limited clinical efficacy of these VEGF and VEGFR inhibitors for the treatment of ACC. Nonetheless pre-clinical data suggest increased efficacy of antiangiogenic therapy with sunitinib when combined with ERK pathway inhibitor in ACC indicating that further antiangiogenic therapy may indeed show antitumor efficacy.[69]

\section{Platelet-derived growth factor receptor (PDGFR) signaling pathway}

Platelet-derived growth factor (PDGF) was one of the first identified polypeptide growth factors identified that signals through a cell surface tyrosine kinase receptor to stimulate various cellular functions including growth, proliferation, and differentiation. Since then, several related genes have been identified constituting a family of ligands (primarily PDGF- $\alpha$ and $-\beta$ ) and their cognate receptors (PDGFR- $\alpha$ and $-\beta$ ) have been identified. PDGFR expression has been demonstrated in a number of solid tumors including ACC.[70, 71] These results suggested that imatinib, a small molecule inhibitor of the c-ABL, PDGFR and stem cell ligand receptor (c-KIT) tyrosine kinases, could potentially have activity in ACC. A phase II study testing imatinib in patients with metastatic solid tumors expressing PDGFR or c-KIT included 4 patients with metastatic ACC, but none of those patients showed clinical response to therapy.[71] On the other hand, another study exploring the combination of imatinib with dacarbazine and capecitabine, in patients with advanced endocrine malignancies documented tumor responses in 2 out of 7 patients with metastatic ACC.[72] 


\section{Epidermal growth factor receptor (EGFR) signaling}

EGFR family is part of a complex signaltransduction network that is central to several critical cellular processes.[73] EGFR has been show to be overexpressed in ACC when compared to adrenal adenomas and normal tissue suggesting the potential use of EGFR expression as a marker of malignancy. $[74,75]$. EGFR amplification by FISH and polysomy of chromosome 7 are noted to be more frequent in ACC specimens compared to adrenocortical adenomas.[76] Sequencing of the EGFR gene in 30 cases did not reveal mutations that are usually associated with response to EGFR tyrosine kinase inhibitors such as erlotinib.[75] Nevertheless, inhibition of EGFR signaling was able to reduce cell viability in ACC lines in vitro.[77] Ten patients with heavily pretreated metastatic $\mathrm{ACC}$ were treated with erlotinib and gemcitabine, but clinical activity was seen in only one patient with reduction in the size of liver metastasis leading to PFS of 8 months. [78] Despite the frequent expression of EGFR, the rarity of activating mutations predictive of response to EGFR tyrosine kinase inhibitors (TKIs) makes unlikely that this class of drugs will be clinically effective for ACC.

\section{Fibroblast growth factor receptor (FGFR) signaling}

Genetic studies have identified disturbances in other signaling pathways such as the FGFR cascade. $[79,80]$ For instance, FGFR4 has been found to be overexpressed in ACC, particularly in the pediatric population.[81] FGFR4 expression was assessed in 57 ACC tumors with overexpression demonstrated in $65 \%$ of specimens. In adults, FGFR4 overexpression and amplification (identified in $13 \%$ of pediatric tumors and $30 \%$ of adults) was associated with worse outcomes.[82] A phase II trial investigating the efficacy of dovitinib, a tyrosine kinase inhibitor with nonselective activity against the FGFR, included 17 patients with unresectable ACC. [83] One partial response was documented but $23 \%$ of patients achieved stable disease lasting $>6$ months. These preliminary results support the current investigation of the potential role of selective FGFR inhibitors for treatment of ACC, particularly in tumors with FGFR overexpression or carrying other genetic aberrations such as amplifications, activating mutations or gene fusions.

\section{Inhibitors of steroidogenesis}

Acetyl-CoA acetyltransferase 1 (ACAT1) catalyzes cholesterol ester formation from cholesterol and long- chain fatty acyl-CoA in adrenal glands and is important in creating a reservoir of substrate for steroid biosynthesis making this enzyme a potential therapeutic target for ACC. A selective inhibitor of ACAT1 (ATR-101-001) is currently undergoing investigation in a phase I study recruiting patients with advanced ACC (NCT01898715). $[84,85]$ Based on the premise that many ACCs require substantial intracellular cholesterol as a substrate for steroidogenesis, drugs capable of disrupting cholesterol uptake have therapeutic potential in ACC. In fact, synthetic high-density lipoprotein (HDL) nanoparticles that inhibit the cholesterol transporters SR-BI inhibited cortisol production in ACC cell lines and enhanced the apoptosis induced by etoposide, cisplatin or mitotane. [86] Synthetic HDL nanoparticles are undergoing active investigation as novel anti-cancer agents and hold promise for the treatment of ACC. [87, 88]

Steroidogenic factor 1 (SF-1) is a nuclear transcription factor critical in the development of steroidogenic tissues such as the adrenal glands.[89] SF-1 also induces proliferation of ACC cell lines and tumor growth in vivo.[90] SF-1 inhibitors inhibited the proliferation elicited by SF-1 overexpression in vitro suggesting a possible therapeutic potential.[91] Furthermore, increased expression of SF-1 among 167 ACC tumors was associated with worse prognosis independent of tumor staging.[92] The ongoing expansion of knowledge regarding SF-1 regulated genes may lead to novel therapeutic targets.[93]

\section{FUTURE POTENTIAL TARGETS}

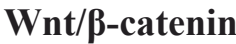

$\beta$-catenin is an important component of the adrenal cortex differentiation through the Wnt signaling pathway. [94] After translocation into the nucleus, $\beta$-catenin along with the $\mathrm{T}$ cell factor/lymphoid enhancing factor (Tcf/ Lef) family of transcription factors induces Wnt target gene expression.[95, 96] The most common genetic alteration identified among 77 ACC tumors by exome sequencing and single nucleotide polymorphism (SNP) array analysis were homozygous deletions in the ZNRF3 gene.[11] This gene encodes a cell surface E3 ubiquitin ligase and is a potential new tumor suppressor gene related to the $\beta$-catenin pathway. Other mutations in genes of the $\beta$-catenin pathway detected in ACC included $A P C$ $(2 \%)$ and $C T N N B 1$ ( $\beta$-catenin gene) $(16 \%)$ found in $30 \%$ of analyzed tumors.[11] In addition, $\beta$-catenin nuclear expression assessed by immunohistochemistry and the presence of mutations in the CTNNB1 and APC genes represented independent prognostic factors in patients with resected ACC.[97] The therapeutic potential of this 
pathway was suggested by pre-clinical data showing that a small-molecule inhibitor of the Tcf $/ \beta$-catenin complex (PKF115-584) induced apoptosis in ACC cell lines carrying mutations in $\beta$-catenin.[98] While there have been significant advances in therapeutic strategies targeting the Wnt pathway, we are not aware of any preliminary clinical results or ongoing trials specific for ACC.[99] Conversely, pre-clinical data support that $\mathrm{Wnt} / \beta$-catenin pathway targeted therapy with anti-Wnt monoclonal antibody can induce apoptosis in a wide variety of cancer cells and suppress tumor growth in xenograft model.[100, 101] In addition, interactions between the $\mathrm{Wnt} / \beta$-catenin and other important intracellular pathways have been proposed. For instance, inhibition of $\gamma$-secretase, which is a key component in the Notch extra-cellular signal transduction pathway showed significant anti-tumor activity in patients desmoid tumors (ORR 71.4\%) in a phase I trial.[102, 103] CTNNB1 mutations are observed is as much as $85 \%$ of desmoid tumors, which may indicate potential interactions between the Notch and Wnt/ $\beta$-catenin pathways.[104]

\section{DNA methylation}

DNA methylation has been studied in ACC.[40] The methylation patterns of $\mathrm{CpG}$ islands in promoter regions were analyzed in $51 \mathrm{ACC}$ and 84 adrenal adenoma specimens. Two unsupervised hierarchical clusters of methylation profiles were identified and the global level of methylation was significantly associated with survival. Among the 25 genes with an inverse correlation between methylation and expression were H19, GSTM1, GSTP1, G0S2.[105] These findings are consistent with results showing reduced expression of $\mathrm{H} 19$ in $\mathrm{ACC}$ as a function of loss of maternal allele with the duplication of paternal allele, leading to biallelic expression of IGF2 gene and decrease in $H 19$ and p57kip2 expression. [45, 50] Also, $\mathrm{ACC}$ cells lines were treated with the cytosine methylation inhibitor 5-aza-2'-deoxycytine as an attempt to reduce the methylation of $H 19$ promoter and thereby increase its expression. Indeed, the treatment increased H19 mRNA expression, inhibited IGF-2 mRNA and decreased cellular proliferation.[106] These results provide a rationale to further investigate the efficacy of DNA demethylating agents in ACC.

\section{Estrogen receptors}

There is evidence in solid tumors of an interaction between the IGF signaling pathway and estrogens.[107, 108] ACC cell model (H295R) showed that estrogen receptor ER $\beta$ is significantly more expressed then ER $\alpha$. [109] Tumor tissue PCR and immunohistochemistry based analysis showed that ER $\beta$ is present in normal adrenal gland tissue and ACC.[110, 111] In addition, the apoptotic effects of 4-hydroxytamoxifen in H295R cells may be consequent to the enhanced levels of ER $\beta$ which stimulate the expression of FasL interacting with activating protein (AP)-1 sites located within its promoter sequence.[109] Further exploration of the ER pathway and its interaction with other cellular biologic processes in ACC may be of potential interest.

\section{Hepatocyte growth factor (HGF)/ c-Met pathway}

c-Met is a transmembrane tyrosine kinase receptor naturally activated by its ligand HGF. Activation of this pathway through mutations or overexpression can lead to cellular proliferation and metastasis in several solid tumors.[112] Also, c-Met expression in solid tumors has been associated with a more aggressive cancer phenotype.[113-115] Transcriptome analysis of ACC cells documented activation of the c-Met pathway in ACC cells, and treatment of ACC cells with HGF increased cell proliferation both in vivo and in vitro.[116] Consistent with these results, cabozantinib, a tyrosine kinase inhibitor with activity against VEGF-R and c-Met inhibited ACC tumor growth in vivo.[116] To the best of our knowledge, there are no clinical data showing efficacy of c-Met pathway inhibitors for the treatment of ACC, but these preliminary results support further investigation.

\section{MicroRNAs}

MicroRNAs (miRNAs) are noncoding RNA molecules that are involved in cellular processes related to post-transcriptional regulation, and some have recently been correlated with the development and progression of various neoplasms.[117] In ACC, global alterations and deregulations in the expression of miRNAS have been reported.[118, 119] While most studies have attempted to identify miRNAs that could help to distinguishing adenomas from ACC or other tumors, a few recent studies have addressed the potential roles of these molecules in predicting response to therapy. For example, both miR483-5p and miR-7, have been shown to regulate the expression of apoptotic pathways, making these molecules attractive for anticancer therapy.[120,121]

\section{Immune system}

Studies investigating immunotherapy strategies in ACC provide preliminary evidence that anti-tumor immune response could be of relevance. Based on the wide expression of the steroidogenic acute regulatory protein (StAR) in adrenal tissue and ACC cell models, a specific immune response against this antigen was elicited using an immunization protocol with DNA plasmids and recombinant vaccinia virus vectors and resulted in an anti-tumor effect in a xenograft model utilizing tumor cell 
Table 1: Current ongoing studies on advanced ACC at www.clinicaltrials.gov*

\begin{tabular}{|c|c|c|c|c|c|}
\hline Drug & Target & Phase & $\boldsymbol{n}$ & Study population & $\begin{array}{c}\text { Clinicaltrials. } \\
\text { gov ID }\end{array}$ \\
\hline ATR-101 & $\begin{array}{l}\text { Acyl- } \\
\text { coenzymeA:cholesterol } \\
\text { O-acyltransferase }\end{array}$ & I & 59 & ACC & NCT01898715 \\
\hline Gossypol acetic acid & Bcl-2 & II & 29 & ACC & NCT00848016 \\
\hline TKM-080301 & Polo-like Kinase & I/II & 68 & Solid tumor allows ACC & NCT01262235 \\
\hline Avelumab & $\begin{array}{c}\text { Programmed cell death- } \\
\text { ligand 1 }\end{array}$ & I & Not provided & Solid tumor allows ACC & NCT01772004 \\
\hline Gefitinib & $\begin{array}{c}\text { Epidermal growth factor } \\
\text { receptor }\end{array}$ & II & 33 & ACC & NCT00215202 \\
\hline $\begin{array}{c}\text { Tamoxifen } \\
\text { cisplatin/doxorubicin }\end{array}$ & $\begin{array}{c}\text { Immunomodulation and } \\
\text { Human epidermal growth } \\
\text { factor receptor 2 (Her2) }\end{array}$ & II & 15 & Solid tumor allows ACC & NCT00002608 \\
\hline $\begin{array}{l}\text { Interleukin-12 and } \\
\text { trastuzumab }\end{array}$ & $\begin{array}{c}\text { Farnesyltransferase } \\
\text { allows ACC }\end{array}$ & I & 24 & Solid tumor allows ACC & NCT00005842 \\
\hline $\begin{array}{l}\text { Tipifarnib and } \\
\text { trastuzumab }\end{array}$ & Deacetylase & I & 75 & Solid tumor allows ACC & NCT00020579 \\
\hline Entinostat & N-Cadherin & II & Not provided & Solid tumor N-cadherin + & NCT00264433 \\
\hline ADH-1 & $\begin{array}{c}\text { Programs ACC } \\
\text { Pembrolizumab cell death 1 }\end{array}$ & II & 39 & ACC & NCT02673333 \\
\hline
\end{tabular}

* Accessed at www.clinicaltrials.gov on February $11^{\text {th }}, 2016$

line expressing StAR.[122-125] Another study describing vaccination of two patients with metastatic ACC using autologous dendritic cells pulsed with autologous tumor lysate showed tumor-specific immune response in spite of excessive production of glucocorticoids by the tumor.[126] The anti-neoplastic activity resulting from immunotherapy strategies (e.g., checkpoint inhibitors anti-CTLA-4 and anti-PD-1 antibodies) for the treatment of solid tumors such as melanoma and non-small cell lung cancer has driven the interest to explore its potential clinical efficacy in ACC.[127-130] Tumor membrane and tumor infiltrating mononuclear cells were assessed for PD-L1 expression through immunohistochemistry in 27 patients with resected ACC. There was no correlation between PD-L1 expression and overall survival, higher tumor grade or stage at diagnosis.[131] The role of immune checkpoints in the pathophysiology of ACC and its possible therapeutic implication remains to be determined. Clinical trials evaluating this strategy will be soon recruiting patients (NCT02673333, NCT02720484 and NCT02720484). [132-134]

Another potential target is interleukin-13 receptor $\alpha 2$ (IL-13R $\alpha 2$ ), which is a high-affinity receptor for the Th2-derived cytokine interleukin-13 (IL- 13).[135] IL-13R $\alpha 2$ is significantly overexpressed in ACCs as compared to normal adrenocortical tissues and benign adrenocortical tumors.[136] IL-13-PE is a chimeric fusion protein consisting of human IL-13 and a truncated form of Pseudomonas exotoxin A.[136] A phase I trial of IL-13-
PE in ACC expressing IL-13R $\alpha 2$ showed stable disease among 3/6 patients lasting for 2-5.5 months[137] IL-13$\mathrm{PE}$ at dose of $1-2 \mathrm{lg} / \mathrm{kg}$ was administered intravenously (IV) on day 1, 3, and 5 in a 4-week cycle. Dose-limiting toxicities were observed at $2 \mathrm{lg} / \mathrm{kg}$, at which patients exhibited thrombocytopenia and renal insufficiency without requiring dialysis. A possible limitation is that neutralizing antibodies developed in $67 \%$ of the patients in high titers.

\section{DISCUSSION}

As of today, chemotherapy remains the standard of care treatment for the treatment of locally advanced or metastatic ACC. The FIRM-ACT indicated that combination of mitotane with etoposide, doxorubicin and cisplatin (EDPM) promotes PFS prolongation in patients with metastatic ACC compared to treatment with mitotane plus streptozocin.[36] Nonetheless, EDPM is associated with serious adverse events in greater than $50 \%$ of patients including myelosuppression, cardiovascular or thromboembolic events, infection, neurotoxicity and general health deterioration. For patients with good performance status, EPDM seems to be a reasonable option, whereas mitotane combined with streptozocin could be offered to patients with poorer performance status.[17]

As reviewed above, many early phase studies have been conducted in ACC in the past years, but no 
breakthrough targeted therapy trial has been reported thus far (Figure 2). IGFR, while a promising target given the high IGFR/mTOR pathway activation in ACC, failed as predictive marker of benefit with anti IGFR therapy. [40] The phase III trial of linsitinib versus placebo in ACC was closed due to the lack of demonstration of overall survival benefit at interim analysis.[48] The simultaneous targeting of the IGFR and mTOR showed more promising results in one phase I trial with 11 out of 26 patients experiencing stable disease after 6 months of therapy, suggesting potential efficacy from combinatory strategies.[55] Agents targeting the VEGFRs and other tyrosine kinase receptors such as cKIT, EGFR and FGFR have not shown significant antitumor activity. [63, 65, 67, $68,72,78,83]$ While interesting pre-clinical data of other potential targets for ACC (e.g., steroidogenic factor 1, c-Met pathway, estrogen receptors, DNA methylation) are emerging, an expansion of immunotherapy translational studies would also be desirable.[92, 106, 109, 116, 131] Importantly, several studies have explored the genomic landscape of this rare malignancy using next generation sequencing approaches.[11, 79, 138-145] These studies highlight not only the significant tumor heterogeneity inherent to ACC, but they were also able to define groups of different prognosis based on the mutational profiles.[11, 140] In the study by Ross et al, clinical specimens from 29 patients with metastatic or locally advanced adrenocortical carcinoma were sequenced.[138] In 17 (59\%) of ACC, at least one genomic alteration was associated with an available therapeutic or a mechanism-based clinical trial. Poli et al reported a different proteomic profile in adrenocortical carcinoma compared with normal adrenal cortex characterized by overexpression of mainly metabolic enzymes that can be a potential target for novel therapeutics.[146]

These studies have identified recurring mutations in several genes such as ZNRF3 (20\%), CTNNB1 (14\%), TP53 (14\%), CDKN2A (11\%), RB1 (5\%), MEN (16\%), $D A X X(5 \%), M E D 12(3 \%)$ and TERT (5\%).[11] Despite the identification of common genetic abnormalities, the

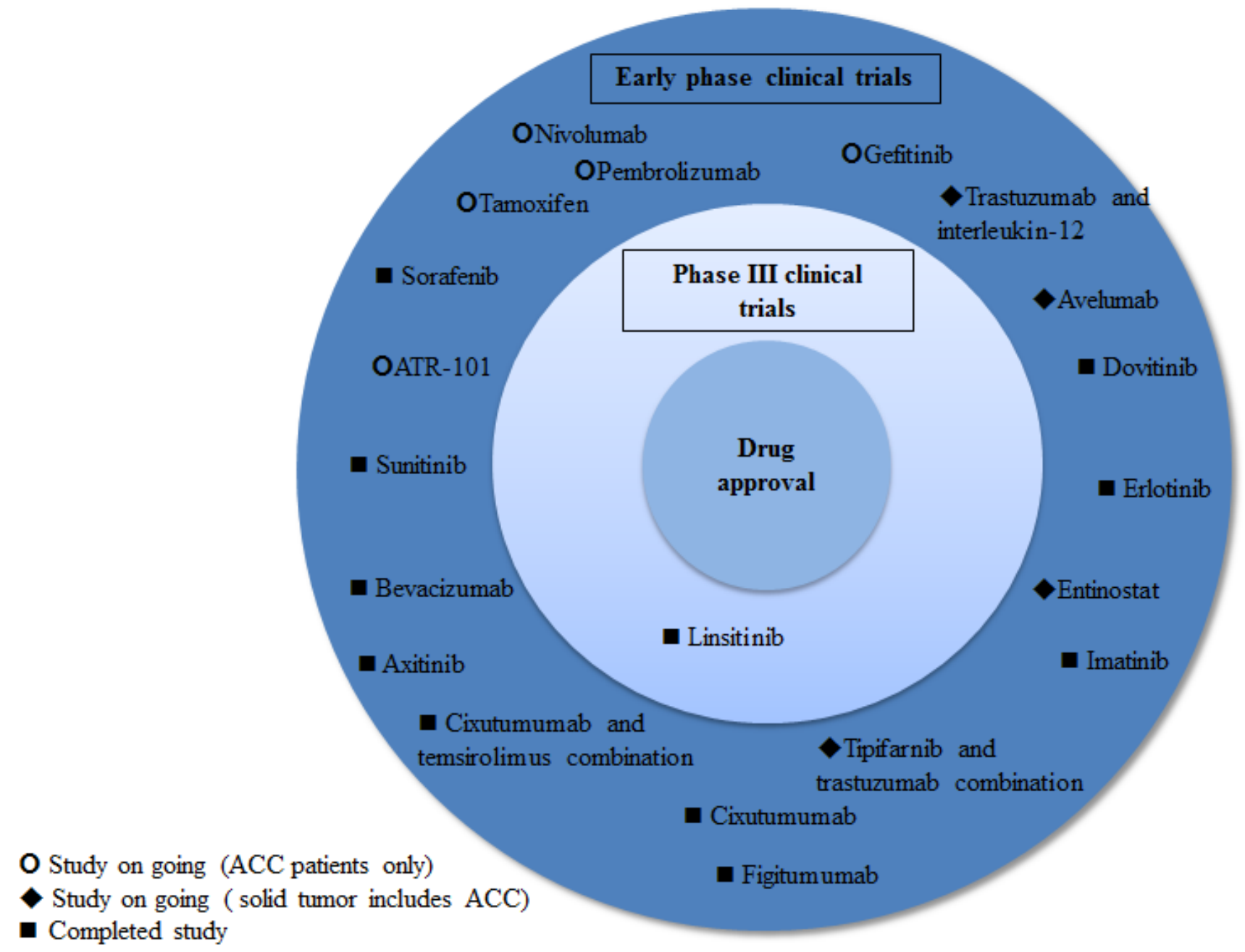

Figure 2: Targeted agents and immune checkpoint inhibitors studied and under development in ACC 
development of targeted therapies for this disease has been thwarted by the rarity of ACC as illustrated by the small sample sizes ranging from 8 to 132 tumor samples in these studies characterizing the genomic alterations. In addition, the construction of valid prognostic and predictive multivariable models incorporating clinicopathological and genomic characteristics are also hampered by the scarcity of the ACC tumor tissue. Comprehensive genomic profiling of ACC tumor samples is underway through The Cancer Genome Atlas program (TCGA) and final results are expected in the near future that will certainly add important information to guide future drug development. [147]

Another corollary to the low incidence of ACC is the challenge of conducting prospective biomarker-based clinical trials. As in some instances, ACC represents an underrepresented population of phase I or phase II basket trials (Table 1). Conversely, collaborations have been fostered already such as the European Network for the Study of Adrenal tumors (ENSAT-CANCER) which offers a virtual research environment with a digitally interconnected infrastructure for distributed clinicians specializing in rare adrenal tumors to communicate and collaborate with distributed biomedical research communities.[148] Indeed large studies such as the FIRM ACT trial epitomize the successful endeavor of ACC treatment development insofar it enrolled 304 patients with ACC from 12 different countries.

Other international collaborations exist in order to increase the clinicopathological datasets, tissue banking, that ultimately will enable biomarker-based clinical studies. For example, the German Adrenocortical Carcinoma Registry is among those projects in which data will be collected for future consideration of prospective studies and facilitate accrual of patients (NCT00453674). [149] Similarly, the National Cancer Institute (NCI) has initiated both prospective clinical data collection, as well as tissue sample and blood sample acquisition of patients with ACC to further develop the understanding of this malignancy (NCT02015026).[150] Furthermore combination of already available and new targeted therapies is likely to optimize tumor response to treatments in development and ultimately prolong survival in patients with ACC.[151]

\section{ACKNOWLEDGMENTS}

None.

\section{CONFLICTS OF INTEREST}

The authors declare that they have no conflicts of interest.

\section{REFERENCES}

1. Golden SH, Robinson KA, Saldanha I, Anton B and Ladenson PW. Clinical review: Prevalence and incidence of endocrine and metabolic disorders in the United States: a comprehensive review. J Clin Endocrinol Metab. 2009; 94:1853-1878.

2. Wooten MD and King DK. Adrenal cortical carcinoma. Epidemiology and treatment with mitotane and a review of the literature. Cancer. 1993; 72:3145-3155.

3. Michalkiewicz E, Sandrini R, Figueiredo B, Miranda EC, Caran E, Oliveira-Filho AG, Marques R, Pianovski MA, Lacerda L, Cristofani LM, Jenkins J, Rodriguez-Galindo $\mathrm{C}$ and Ribeiro RC. Clinical and outcome characteristics of children with adrenocortical tumors: a report from the International Pediatric Adrenocortical Tumor Registry. J Clin Oncol. 2004; 22:838-845.

4. O’Neill CJ, Spence A, Logan B, Suliburk JW, Soon PS, Learoyd DL, Sidhu SB and Sywak MS. Adrenal incidentalomas: risk of adrenocortical carcinoma and clinical outcomes. J Surg Oncol. 2010; 102:450-453.

5. Allan BJ, Thorson CM, Van Haren RM, Parikh PP and Lew JI. Risk of concomitant malignancy in hyperfunctioning adrenal incidentalomas. J Surg Res. 2013; 184:241-246.

6. Mansmann G, Lau J, Balk E, Rothberg M, Miyachi Y and Bornstein SR. The clinically inapparent adrenal mass: update in diagnosis and management. Endocr Rev. 2004; 25:309-340.

7. Barzon L, Sonino N, Fallo F, Palu G and Boscaro M. Prevalence and natural history of adrenal incidentalomas. Eur J Endocrinol. 2003; 149:273-285.

8. Weiss LM, Medeiros LJ and Vickery AL, Jr. Pathologic features of prognostic significance in adrenocortical carcinoma. Am J Surg Pathol. 1989; 13:202-206.

9. Pennanen M, Heiskanen I, Sane T, Remes S, Mustonen H, Haglund $\mathrm{C}$ and Arola J. Helsinki score-a novel model for prediction of metastases in adrenocortical carcinomas. Hum Pathol. 2015; 46:404-410.

10. Duregon E, Fassina A, Volante M, Nesi G, Santi R, Gatti G, Cappellesso R, Dalino Ciaramella P, Ventura L, Gambacorta M, Dei Tos AP, Loli P, Mannelli M, Mantero F, Berruti A, Terzolo M, et al. The reticulin algorithm for adrenocortical tumor diagnosis: a multicentric validation study on 245 unpublished cases. Am J Surg Pathol. 2013; $37: 1433-1440$

11. Assie G, Letouze E, Fassnacht M, Jouinot A, Luscap W, Barreau O, Omeiri H, Rodriguez S, Perlemoine K, Rene-Corail F, Elarouci N, Sbiera S, Kroiss M, Allolio B, Waldmann J, Quinkler M, et al. Integrated genomic characterization of adrenocortical carcinoma. Nat Genet. 2014; 46:607-612.

12. Else T, Kim AC, Sabolch A, Raymond VM, Kandathil A, Caoili EM, Jolly S, Miller BS, Giordano TJ and Hammer GD. Adrenocortical carcinoma. Endocr Rev. 2014; 35:282- 
326.

13. Wasserman JD, Novokmet A, Eichler-Jonsson C, Ribeiro RC, Rodriguez-Galindo C, Zambetti GP and Malkin D. Prevalence and functional consequence of TP53 mutations in pediatric adrenocortical carcinoma: a children's oncology group study. J Clin Oncol. 2015; 33:602-609.

14. Raymond VM, Everett JN, Furtado LV, Gustafson SL, Jungbluth CR, Gruber SB, Hammer GD, Stoffel EM, Greenson JK, Giordano TJ and Else T. Adrenocortical carcinoma is a lynch syndrome-associated cancer. J Clin Oncol. 2013; 31:3012-3018.

15. Ribeiro RC, Sandrini F, Figueiredo B, Zambetti GP, Michalkiewicz E, Lafferty AR, DeLacerda L, Rabin M, Cadwell C, Sampaio G, Cat I, Stratakis CA and Sandrini R. An inherited p53 mutation that contributes in a tissuespecific manner to pediatric adrenal cortical carcinoma. Proc Natl Acad Sci U S A. 2001; 98:9330-9335.

16. Else T. Association of adrenocortical carcinoma with familial cancer susceptibility syndromes. Mol Cell Endocrinol. 2012; 351:66-70.

17. Berruti A, Baudin E, Gelderblom H, Haak HR, Porpiglia F, Fassnacht M, Pentheroudakis G and Group EGW. Adrenal cancer: ESMO Clinical Practice Guidelines for diagnosis, treatment and follow-up. Ann Oncol. 2012; 23 Suppl 7:vii131-138.

18. Hutter AM, Jr. and Kayhoe DE. Adrenal cortical carcinoma. Results of treatment with o,p'DDD in 138 patients. Am J Med. 1966; 41:581-592.

19. Nelson AA and Woodard G. Severe adrenal cortical atrophy (cytotoxic) and hepatic damage produced in dogs by feeding 2,2-bis(parachlorophenyl)-1,1-dichloroethane (DDD or TDE). Arch Pathol (Chic). 1949; 48:387-394.

20. Baudin E, Leboulleux S, Al Ghuzlan A, Chougnet C, Young J, Deandreis D, Dumont F, Dechamps F, Caramella C, Chanson P, Lanoy E, Borget I and Schlumberger M. Therapeutic management of advanced adrenocortical carcinoma: what do we know in 2011? Horm Cancer. 2011; 2:363-371.

21. Vogelstein B, Papadopoulos N, Velculescu VE, Zhou S, Diaz LA, Jr. and Kinzler KW. Cancer genome landscapes. Science. 2013; 339:1546-1558.

22. Barzon L, Fallo F, Sonino N, Daniele O and Boscaro M. Adrenocortical carcinoma: experience in 45 patients. Oncology. 1997; 54:490-496.

23. Haak HR, Hermans J, van de Velde CJ, Lentjes EG, Goslings BM, Fleuren GJ and Krans HM. Optimal treatment of adrenocortical carcinoma with mitotane: results in a consecutive series of 96 patients. Br J Cancer. 1994; 69:947-951.

24. Veytsman I, Nieman L and Fojo T. Management of endocrine manifestations and the use of mitotane as a chemotherapeutic agent for adrenocortical carcinoma. J Clin Oncol. 2009; 27:4619-4629.
25. Baudin E, Pellegriti G, Bonnay M, Penfornis A, Laplanche A, Vassal $G$ and Schlumberger M. Impact of monitoring plasma 1,1-dichlorodiphenildichloroethane (o,p'DDD) levels on the treatment of patients with adrenocortical carcinoma. Cancer. 2001; 92:1385-1392.

26. Williamson SK, Lew D, Miller GJ, Balcerzak SP, Baker LH and Crawford ED. Phase II evaluation of cisplatin and etoposide followed by mitotane at disease progression in patients with locally advanced or metastatic adrenocortical carcinoma: a Southwest Oncology Group Study. Cancer. 2000; 88:1159-1165.

27. Bonacci R, Gigliotti A, Baudin E, Wion-Barbot N, Emy P, Bonnay M, Cailleux AF, Nakib I, Schlumberger M and Reseau C. Cytotoxic therapy with etoposide and cisplatin in advanced adrenocortical carcinoma. Br J Cancer. 1998; 78:546-549.

28. Khan TS, Sundin A, Juhlin C, Wilander E, Oberg K and Eriksson B. Vincristine, cisplatin, teniposide, and cyclophosphamide combination in the treatment of recurrent or metastatic adrenocortical cancer. Med Oncol. 2004; 21:167-177.

29. Abraham J, Bakke S, Rutt A, Meadows B, Merino M, Alexander R, Schrump D, Bartlett D, Choyke P, Robey R, Hung E, Steinberg SM, Bates S and Fojo T. A phase II trial of combination chemotherapy and surgical resection for the treatment of metastatic adrenocortical carcinoma: continuous infusion doxorubicin, vincristine, and etoposide with daily mitotane as a P-glycoprotein antagonist. Cancer. 2002; 94:2333-2343.

30. Fassnacht $M$, Libe $R$, Kroiss $M$ and Allolio $B$. Adrenocortical carcinoma: a clinician's update. Nat Rev Endocrinol. 2011; 7:323-335.

31. Fassnacht $\mathrm{M}$ and Allolio B. What is the best approach to an apparently nonmetastatic adrenocortical carcinoma? Clin Endocrinol (Oxf). 2010; 73:561-565.

32. Kerkhofs TM, Ettaieb MH, Hermsen IG and Haak HR. Developing treatment for adrenocortical carcinoma. Endocr Relat Cancer. 2015; 22:R325-338.

33. Ronchi CL, Sbiera S, Kraus L, Wortmann S, Johanssen S, Adam P, Willenberg HS, Hahner S, Allolio B and Fassnacht M. Expression of excision repair cross complementing group 1 and prognosis in adrenocortical carcinoma patients treated with platinum-based chemotherapy. Endocr Relat Cancer. 2009; 16:907-918.

34. Volante M, Terzolo M, Fassnacht M, Rapa I, Germano A, Sbiera S, Daffara F, Sperone P, Scagliotti G, Allolio B, Papotti $\mathrm{M}$ and Berruti A. Ribonucleotide reductase large subunit (RRM1) gene expression may predict efficacy of adjuvant mitotane in adrenocortical cancer. Clin Cancer Res. 2012; 18:3452-3461.

35. Malandrino P, Al Ghuzlan A, Castaing M, Young J, Caillou B, Travagli JP, Elias D, de Baere T, Dromain C, Paci A, Chanson P, Schlumberger M, Leboulleux S and Baudin E. Prognostic markers of survival after combined 
mitotane- and platinum-based chemotherapy in metastatic adrenocortical carcinoma. Endocr Relat Cancer. 2010; 17:797-807.

36. Fassnacht M, Terzolo M, Allolio B, Baudin E, Haak H, Berruti A, Welin S, Schade-Brittinger C, Lacroix A, Jarzab B, Sorbye H, Torpy DJ, Stepan V, Schteingart DE, Arlt W, Kroiss M, et al. Combination chemotherapy in advanced adrenocortical carcinoma. N Engl J Med. 2012; 366:21892197.

37. Hermsen IG, Fassnacht M, Terzolo M, Houterman S, den Hartigh J, Leboulleux S, Daffara F, Berruti A, Chadarevian R, Schlumberger M, Allolio B, Haak HR and Baudin E. Plasma concentrations of o,p'DDD, o,p'DDA, and o,p'DDE as predictors of tumor response to mitotane in adrenocortical carcinoma: results of a retrospective ENS@T multicenter study. J Clin Endocrinol Metab. 2011; 96:18441851.

38. De Meyts P. Insulin and its receptor: structure, function and evolution. Bioessays. 2004; 26:1351-1362.

39. Pollak M. Insulin and insulin-like growth factor signalling in neoplasia. Nat Rev Cancer. 2008; 8:915-928.

40. Lerario AM, Moraitis A and Hammer GD. Genetics and epigenetics of adrenocortical tumors. Mol Cell Endocrinol. 2014; 386:67-84.

41. Boulle N, Logie A, Gicquel C, Perin L and Le Bouc Y. Increased levels of insulin-like growth factor II (IGF-II) and IGF-binding protein-2 are associated with malignancy in sporadic adrenocortical tumors. J Clin Endocrinol Metab. 1998; 83:1713-1720.

42. Gicquel C, Bertagna X, Gaston V, Coste J, Louvel A, Baudin E, Bertherat J, Chapuis Y, Duclos JM, Schlumberger M, Plouin PF, Luton JP and Le Bouc Y. Molecular markers and long-term recurrences in a large cohort of patients with sporadic adrenocortical tumors. Cancer Res. 2001; 61:67626767.

43. Guillaud-Bataille M, Ragazzon B, de Reynies A, Chevalier C, Francillard I, Barreau O, Steunou V, Guillemot J, Tissier F, Rizk-Rabin M, Rene-Corail F, Al Ghuzlan A, Assie G, Bertagna X, Baudin E, Le Bouc Y, et al. IGF2 promotes growth of adrenocortical carcinoma cells, but its overexpression does not modify phenotypic and molecular features of adrenocortical carcinoma. PLoS One. 2014; 9:e103744.

44. Almeida MQ, Fragoso MC, Lotfi CF, Santos MG, Nishi MY, Costa MH, Lerario AM, Maciel CC, Mattos GE, Jorge AA, Mendonca BB and Latronico AC. Expression of insulin-like growth factor-II and its receptor in pediatric and adult adrenocortical tumors. J Clin Endocrinol Metab. 2008; 93:3524-3531.

45. Ribeiro TC and Latronico AC. Insulin-like growth factor system on adrenocortical tumorigenesis. Mol Cell Endocrinol. 2012; 351:96-100.

46. Erickson LA, Jin L, Sebo TJ, Lohse C, Pankratz VS, Kendrick ML, van Heerden JA, Thompson GB, Grant
CS and Lloyd RV. Pathologic features and expression of insulin-like growth factor-2 in adrenocortical neoplasms. Endocr Pathol. 2001; 12:429-435.

47. Jones RL, Kim ES, Nava-Parada P, Alam S, Johnson FM, Stephens AW, Simantov R, Poondru S, Gedrich R, Lippman SM, Kaye SB and Carden CP. Phase I study of intermittent oral dosing of the insulin-like growth factor-1 and insulin receptors inhibitor OSI-906 in patients with advanced solid tumors. Clin Cancer Res. 2015; 21:693-700.

48. Fassnacht M, Berruti A, Baudin E, Demeure MJ, Gilbert J, Haak H, Kroiss M, Quinn DI, Hesseltine E, Ronchi CL, Terzolo M, Choueiri TK, Poondru S, Fleege T, Rorig R, Chen J, et al. Linsitinib (OSI-906) versus placebo for patients with locally advanced or metastatic adrenocortical carcinoma: a double-blind, randomised, phase 3 study. Lancet Oncol. 2015; 16:426-435.

49. Mulvihill MJ, Cooke A, Rosenfeld-Franklin M, Buck E, Foreman K, Landfair D, O'Connor M, Pirritt C, Sun Y, Yao Y, Arnold LD, Gibson NW and Ji QS. Discovery of OSI-906: a selective and orally efficacious dual inhibitor of the IGF-1 receptor and insulin receptor. Future Med Chem. 2009; 1:1153-1171.

50. Gicquel C, Bertagna X, Schneid H, Francillard-Leblond M, Luton JP, Girard F and Le Bouc Y. Rearrangements at the $11 \mathrm{p} 15$ locus and overexpression of insulin-like growth factor-II gene in sporadic adrenocortical tumors. J Clin Endocrinol Metab. 1994; 78:1444-1453.

51. Gicquel C, Raffin-Sanson ML, Gaston V, Bertagna X, Plouin PF, Schlumberger M, Louvel A, Luton JP and Le Bouc Y. Structural and functional abnormalities at 11p15 are associated with the malignant phenotype in sporadic adrenocortical tumors: study on a series of 82 tumors. J Clin Endocrinol Metab. 1997; 82:2559-2565.

52. Cohen BD, Baker DA, Soderstrom C, Tkalcevic G, Rossi AM, Miller PE, Tengowski MW, Wang F, Gualberto A, Beebe JS and Moyer JD. Combination therapy enhances the inhibition of tumor growth with the fully human anti-type 1 insulin-like growth factor receptor monoclonal antibody CP-751,871. Clin Cancer Res. 2005; 11:2063-2073.

53. Haluska P, Worden F, Olmos D, Yin D, Schteingart D, Batzel GN, Paccagnella ML, de Bono JS, Gualberto A and Hammer GD. Safety, tolerability, and pharmacokinetics of the anti-IGF-1R monoclonal antibody figitumumab in patients with refractory adrenocortical carcinoma. Cancer Chemother Pharmacol. 2010; 65:765-773.

54. Lerario AM, Worden FP, Ramm CA, Hesseltine EA, Stadler WM, Else T, Shah MH, Agamah E, Rao K and Hammer GD. The combination of insulin-like growth factor receptor 1 (IGF1R) antibody cixutumumab and mitotane as a first-line therapy for patients with recurrent/ metastatic adrenocortical carcinoma: a multi-institutional NCI-sponsored trial. Horm Cancer. 2014; 5:232-239.

55. Naing A, Kurzrock R, Burger A, Gupta S, Lei X, Busaidy N, Hong D, Chen HX, Doyle LA, Heilbrun LK, Rohren E, Ng C, Chandhasin C and LoRusso P. Phase I trial of 
cixutumumab combined with temsirolimus in patients with advanced cancer. Clin Cancer Res. 2011; 17:6052-6060.

56. Naing A, Lorusso P, Fu S, Hong D, Chen HX, Doyle LA, Phan AT, Habra MA and Kurzrock R. Insulin growth factor receptor (IGF-1R) antibody cixutumumab combined with the mTOR inhibitor temsirolimus in patients with metastatic adrenocortical carcinoma. Br J Cancer. 2013; 108:826-830.

57. De Martino MC, Feelders RA, de Herder WW, van Koetsveld PM, Dogan F, Janssen JA, Waaijers AM, Pivonello C, Lamberts SW, Colao A, de Krijger RR, Pivonello R and Hofland LJ. Characterization of the mTOR pathway in human normal adrenal and adrenocortical tumors. Endocr Relat Cancer. 2014; 21:601-613.

58. Fraenkel M, Gueorguiev M, Barak D, Salmon A, Grossman $\mathrm{AB}$ and Gross DJ. Everolimus therapy for progressive adrenocortical cancer. Endocrine. 2013; 44:187-192.

59. Folkman J. Tumor angiogenesis: a possible control point in tumor growth. Ann Intern Med. 1975; 82:96-100.

60. Bernini GP, Moretti A, Bonadio AG, Menicagli M, Viacava P, Naccarato AG, Iacconi P, Miccoli P and Salvetti A. Angiogenesis in human normal and pathologic adrenal cortex. J Clin Endocrinol Metab. 2002; 87:4961-4965.

61. Xu YZ, Zhu Y, Shen ZJ, Sheng JY, He HC, Ma G, Qi YC, Zhao JP, Wu YX, Rui WB, Wei Q, Zhou WL, Xie $X$ and Ning $G$. Significance of heparanase-1 and vascular endothelial growth factor in adrenocortical carcinoma angiogenesis: potential for therapy. Endocrine. 2011; 40:445-451.

62. Hu-Lowe DD, Zou HY, Grazzini ML, Hallin ME, Wickman GR, Amundson K, Chen JH, Rewolinski DA, Yamazaki S, Wu EY, McTigue MA, Murray BW, Kania RS, O'Connor P, Shalinsky DR and Bender SL. Nonclinical antiangiogenesis and antitumor activities of axitinib (AG013736), an oral, potent, and selective inhibitor of vascular endothelial growth factor receptor tyrosine kinases 1, 2, 3 . Clin Cancer Res. 2008; 14:7272-7283.

63. O'Sullivan C, Edgerly M, Velarde M, Wilkerson J, Venkatesan AM, Pittaluga S, Yang SX, Nguyen D, Balasubramaniam $\mathrm{S}$ and Fojo T. The VEGF inhibitor axitinib has limited effectiveness as a therapy for adrenocortical cancer. J Clin Endocrinol Metab. 2014; 99:1291-1297.

64. Wilhelm SM, Carter C, Tang L, Wilkie D, McNabola A, Rong H, Chen C, Zhang X, Vincent P, McHugh M, Cao Y, Shujath J, Gawlak S, Eveleigh D, Rowley B, Liu L, et al. BAY 43-9006 exhibits broad spectrum oral antitumor activity and targets the RAF/MEK/ERK pathway and receptor tyrosine kinases involved in tumor progression and angiogenesis. Cancer Res. 2004; 64:7099-7109.

65. Berruti A, Sperone P, Ferrero A, Germano A, Ardito A, Priola AM, De Francia S, Volante M, Daffara F, Generali D, Leboulleux S, Perotti P, Baudin E, Papotti M and Terzolo M. Phase II study of weekly paclitaxel and sorafenib as second/third-line therapy in patients with adrenocortical carcinoma. Eur J Endocrinol. 2012; 166:451-458.
66. Mendel DB, Laird AD, Xin X, Louie SG, Christensen JG, Li G, Schreck RE, Abrams TJ, Ngai TJ, Lee LB, Murray LJ, Carver J, Chan E, Moss KG, Haznedar JO, Sukbuntherng $\mathrm{J}$, et al. In vivo antitumor activity of SU11248, a novel tyrosine kinase inhibitor targeting vascular endothelial growth factor and platelet-derived growth factor receptors: determination of a pharmacokinetic/pharmacodynamic relationship. Clin Cancer Res. 2003; 9:327-337.

67. Kroiss M, Quinkler M, Johanssen S, van Erp NP, Lankheet N, Pollinger A, Laubner K, Strasburger CJ, Hahner S, Muller HH, Allolio B and Fassnacht M. Sunitinib in refractory adrenocortical carcinoma: a phase II, single-arm, open-label trial. J Clin Endocrinol Metab. 2012; 97:34953503.

68. Wortmann S, Quinkler M, Ritter C, Kroiss M, Johanssen S, Hahner S, Allolio B and Fassnacht M. Bevacizumab plus capecitabine as a salvage therapy in advanced adrenocortical carcinoma. Eur J Endocrinol. 2010; 162:349356.

69. Lin CI, Whang EE, Moalem J and Ruan DT. Strategic combination therapy overcomes tyrosine kinase coactivation in adrenocortical carcinoma. Surgery. 2012; 152:1045-1050.

70. George D. Platelet-derived growth factor receptors: a therapeutic target in solid tumors. Semin Oncol. 2001; 28:27-33.

71. Gross DJ, Munter G, Bitan M, Siegal T, Gabizon A, Weitzen R, Merimsky O, Ackerstein A, Salmon A, Sella A, Slavin S and Israel Glivec in Solid Tumors Study G. The role of imatinib mesylate (Glivec) for treatment of patients with malignant endocrine tumors positive for c-kit or PDGF-R. Endocr Relat Cancer. 2006; 13:535-540.

72. Halperin DM, Phan AT, Hoff AO, Aaron M, Yao JC and Hoff PM. A phase I study of imatinib, dacarbazine, and capecitabine in advanced endocrine cancers. BMC Cancer. 2014; 14:561.

73. Rusch V, Klimstra D, Venkatraman E, Pisters PW, Langenfeld J and Dmitrovsky E. Overexpression of the epidermal growth factor receptor and its ligand transforming growth factor alpha is frequent in resectable non-small cell lung cancer but does not predict tumor progression. Clin Cancer Res. 1997; 3:515-522.

74. Wang CP, Zhang J, Gao J, Liu PP, Wu SF, Zeng X and Liang ZY. [Clinicopathologic features and expression of epidermal growth factor receptor and vascular endothelial growth factor in adrenocortical tumors]. Zhonghua Bing Li Xue Za Zhi. 2012; 41:686-690.

75. Adam P, Hahner S, Hartmann M, Heinrich B, Quinkler M, Willenberg HS, Saeger W, Sbiera S, Schmull S, Voelker HU, Strobel P, Allolio B and Fassnacht M. Epidermal growth factor receptor in adrenocortical tumors: analysis of gene sequence, protein expression and correlation with clinical outcome. Mod Pathol. 2010; 23:1596-1604.

76. Zhang J, Wang C, Gao J, Sun J, Zeng X, Wu S and Liang Z. Adrenal cortical neoplasms: a study of clinicopathological 
features related to epidermal growth factor receptor gene status. Diagn Pathol. 2014; 9:19.

77. Gagliano T, Gentilin E, Tagliati F, Benfini K, Di Pasquale C, Feo C, Falletta S, Riva E, Degli Uberti E and Zatelli MC. Inhibition of epithelial growth factor receptor can play an important role in reducing cell growth and survival in adrenocortical tumors. Biochem Pharmacol. 2015; 98:639648.

78. Quinkler M, Hahner S, Wortmann S, Johanssen S, Adam P, Ritter C, Strasburger C, Allolio B and Fassnacht M. Treatment of advanced adrenocortical carcinoma with erlotinib plus gemcitabine. J Clin Endocrinol Metab. 2008; 93:2057-2062.

79. de Fraipont F, El Atifi M, Cherradi N, Le Moigne G, Defaye G, Houlgatte R, Bertherat J, Bertagna X, Plouin PF, Baudin E, Berger F, Gicquel C, Chabre O and Feige JJ. Gene expression profiling of human adrenocortical tumors using complementary deoxyribonucleic Acid microarrays identifies several candidate genes as markers of malignancy. J Clin Endocrinol Metab. 2005; 90:1819-1829.

80. Laurell C, Velazquez-Fernandez D, Lindsten K, Juhlin C, Enberg U, Geli J, Hoog A, Kjellman M, Lundeberg J, Hamberger B, Larsson C, Nilsson P and Backdahl M. Transcriptional profiling enables molecular classification of adrenocortical tumours. Eur J Endocrinol. 2009; 161:141152.

81. West AN, Neale GA, Pounds S, Figueredo BC, Rodriguez Galindo C, Pianovski MA, Oliveira Filho AG, Malkin D, Lalli E, Ribeiro R and Zambetti GP. Gene expression profiling of childhood adrenocortical tumors. Cancer Res. 2007; 67:600-608.

82. Brito LP, Ribeiro TC, Almeida MQ, Jorge AA, Soares $\mathrm{IC}$, Latronico $\mathrm{AC}$, Mendonca $\mathrm{BB}$, Fragoso $\mathrm{MC}$ and Lerario AM. The role of fibroblast growth factor receptor 4 overexpression and gene amplification as prognostic markers in pediatric and adult adrenocortical tumors. Endocr Relat Cancer. 2012; 19:L11-13.

83. Jesús García-Donas SHP, Guix M, Duran MAC, MéndezVidal MJ, Jiménez-Fonseca P, Laínez N, Mateos LL, Moreno F, Gonzalez ERS, Duran I, Perez FJ, RodriguezMoreno JF, Maciá S, et al. Phase II study of dovitinib in first line metastatic or (non resectable primary) adrenocortical carcinoma (ACC): SOGUG study 2011-03. J Clin Oncol. 2014; 32:5s (suppl; abstr 4588).

84. Aung Naing SF, Habra MA, Chugh R, Kebebew E, Russell J, Welshans D, Fassnacht M, Kroiss M, Goebeler M-E, Ijzerman M, Plaunt MR, Mohideen P, Phillips M, et al. ATR-101 phase 1 clinical study for adrenocortical carcinoma. J Clin Oncol. 2015; 33 (suppl; abstr TPS4585).

85. Phase 1 Study of ATR-101 in Subjects With Advanced Adrenocortical Carcinoma. wwwclinicaltrialsgov. February 11 th, 2016.

86. Subramanian C, Kuai R, Zhu Q, White P, Moon JJ,
Schwendeman A and Cohen MS. Synthetic high-density lipoprotein nanoparticles: A novel therapeutic strategy for adrenocortical carcinomas. Surgery. 2016; 159:284-295.

87. Foit L, Giles FJ, Gordon LI and Thaxton CS. Synthetic high-density lipoprotein-like nanoparticles for cancer therapy. Expert Rev Anticancer Ther. 2015; 15:27-34.

88. Yang S, Damiano MG, Zhang H, Tripathy S, Luthi AJ, Rink JS, Ugolkov AV, Singh AT, Dave SS, Gordon LI and Thaxton CS. Biomimetic, synthetic HDL nanostructures for lymphoma. Proc Natl Acad Sci U S A. 2013; 110:25112516.

89. Val P, Lefrancois-Martinez AM, Veyssiere G and Martinez A. SF-1 a key player in the development and differentiation of steroidogenic tissues. Nucl Recept. 2003; 1:8.

90. Doghman M, Karpova T, Rodrigues GA, Arhatte M, De Moura J, Cavalli LR, Virolle V, Barbry P, Zambetti GP, Figueiredo BC, Heckert LL and Lalli E. Increased steroidogenic factor-1 dosage triggers adrenocortical cell proliferation and cancer. Mol Endocrinol. 2007; $21: 2968$ 2987.

91. Doghman M, Cazareth J, Douguet D, Madoux F, Hodder $\mathrm{P}$ and Lalli E. Inhibition of adrenocortical carcinoma cell proliferation by steroidogenic factor-1 inverse agonists. J Clin Endocrinol Metab. 2009; 94:2178-2183.

92. Sbiera S, Schmull S, Assie G, Voelker HU, Kraus L, Beyer M, Ragazzon B, Beuschlein F, Willenberg HS, Hahner S, Saeger W, Bertherat J, Allolio B and Fassnacht M. High diagnostic and prognostic value of steroidogenic factor-1 expression in adrenal tumors. J Clin Endocrinol Metab. 2010; 95:E161-171.

93. Mizutani T, Kawabe S, Ishikane S, Imamichi Y, Umezawa A and Miyamoto K. Identification of novel steroidogenic factor 1 (SF-1)-target genes and components of the SF-1 nuclear complex. Mol Cell Endocrinol. 2015; 408:133-137.

94. Kim AC, Reuter AL, Zubair M, Else T, Serecky K, Bingham NC, Lavery GG, Parker KL and Hammer GD. Targeted disruption of beta-catenin in Sf1-expressing cells impairs development and maintenance of the adrenal cortex. Development. 2008; 135:2593-2602.

95. Cadoret A, Ovejero C, Terris B, Souil E, Levy L, Lamers WH, Kitajewski J, Kahn A and Perret C. New targets of beta-catenin signaling in the liver are involved in the glutamine metabolism. Oncogene. 2002; 21:8293-8301.

96. El Wakil A and Lalli E. The Wnt/beta-catenin pathway in adrenocortical development and cancer. Mol Cell Endocrinol. 2011; 332:32-37.

97. Gaujoux S, Grabar S, Fassnacht M, Ragazzon B, Launay P, Libe R, Chokri I, Audebourg A, Royer B, Sbiera S, VacherLavenu MC, Dousset B, Bertagna X, Allolio B, Bertherat $\mathrm{J}$ and Tissier F. beta-catenin activation is associated with specific clinical and pathologic characteristics and a poor outcome in adrenocortical carcinoma. Clin Cancer Res. $2011 ; 17: 328-336$. 
98. Doghman M, Cazareth J and Lalli E. The T cell factor/betacatenin antagonist PKF115-584 inhibits proliferation of adrenocortical carcinoma cells. J Clin Endocrinol Metab. 2008; 93:3222-3225.

99. Madan B and Virshup DM. Targeting Wnts at the sourcenew mechanisms, new biomarkers, new drugs. Mol Cancer Ther. 2015; 14:1087-1094.

100. He B, You L, Uematsu K, Xu Z, Lee AY, Matsangou M, McCormick F and Jablons DM. A monoclonal antibody against Wnt-1 induces apoptosis in human cancer cells. Neoplasia. 2004; 6:7-14.

101. You L, He B, Xu Z, Uematsu K, Mazieres J, Fujii N, Mikami I, Reguart N, McIntosh JK, Kashani-Sabet M, McCormick F and Jablons DM. An anti-Wnt-2 monoclonal antibody induces apoptosis in malignant melanoma cells and inhibits tumor growth. Cancer Res. 2004; 64:53855389.

102. Capaccione KM and Pine SR. The Notch signaling pathway as a mediator of tumor survival. Carcinogenesis. 2013; 34:1420-1430.

103. Messersmith WA, Shapiro GI, Cleary JM, Jimeno A, Dasari A, Huang B, Shaik MN, Cesari R, Zheng X, Reynolds JM, English PA, McLachlan KR, Kern KA and LoRusso PM. A Phase I, dose-finding study in patients with advanced solid malignancies of the oral gamma-secretase inhibitor PF03084014. Clin Cancer Res. 2015; 21:60-67.

104. Lazar AJ, Tuvin D, Hajibashi S, Habeeb S, Bolshakov S, Mayordomo-Aranda E, Warneke CL, Lopez-Terrada D, Pollock RE and Lev D. Specific mutations in the betacatenin gene (CTNNB1) correlate with local recurrence in sporadic desmoid tumors. Am J Pathol. 2008; 173:15181527.

105. Barreau O, Assie G, Wilmot-Roussel H, Ragazzon B, Baudry C, Perlemoine K, Rene-Corail F, Bertagna X, Dousset B, Hamzaoui N, Tissier F, de Reynies A and Bertherat J. Identification of a $\mathrm{CpG}$ island methylator phenotype in adrenocortical carcinomas. J Clin Endocrinol Metab. 2013; 98:E174-184.

106. Gao ZH, Suppola S, Liu J, Heikkila P, Janne J and Voutilainen R. Association of H19 promoter methylation with the expression of $\mathrm{H} 19$ and IGF-II genes in adrenocortical tumors. J Clin Endocrinol Metab. 2002; 87:1170-1176.

107. Lee AV, Weng CN, Jackson JG and Yee D. Activation of estrogen receptor-mediated gene transcription by IGF-I in human breast cancer cells. J Endocrinol. 1997; 152:39-47.

108. Zhang S, Li X, Burghardt R, Smith R, 3rd and Safe SH. Role of estrogen receptor (ER) alpha in insulin-like growth factor (IGF)-I-induced responses in MCF-7 breast cancer cells. J Mol Endocrinol. 2005; 35:433-447.

109. Montanaro D, Maggiolini M, Recchia AG, Sirianni R, Aquila S, Barzon L, Fallo F, Ando S and Pezzi V. Antiestrogens upregulate estrogen receptor beta expression and inhibit adrenocortical H295R cell proliferation. J Mol
Endocrinol. 2005; 35:245-256.

110. de Cremoux P, Rosenberg D, Goussard J, Bremont-Weil C, Tissier F, Tran-Perennou C, Groussin L, Bertagna $\mathrm{X}$, Bertherat $\mathrm{J}$ and Raffin-Sanson ML. Expression of progesterone and estradiol receptors in normal adrenal cortex, adrenocortical tumors, and primary pigmented nodular adrenocortical disease. Endocr Relat Cancer. 2008; 15:465-474.

111. Barzon L, Masi G, Pacenti M, Trevisan M, Fallo F, Remo A, Martignoni G, Montanaro D, Pezzi V and Palu G. Expression of aromatase and estrogen receptors in human adrenocortical tumors. Virchows Arch. 2008; 452:181-191.

112. Ma PC, Maulik G, Christensen J and Salgia R. c-Met: structure, functions and potential for therapeutic inhibition. Cancer Metastasis Rev. 2003; 22:309-325.

113. Kaposi-Novak P, Lee JS, Gomez-Quiroz L, Coulouarn C, Factor VM and Thorgeirsson SS. Met-regulated expression signature defines a subset of human hepatocellular carcinomas with poor prognosis and aggressive phenotype. J Clin Invest. 2006; 116:1582-1595.

114. Teng $\mathrm{L}$ and Lu J. cMET as a potential therapeutic target in gastric cancer (Review). Int J Mol Med. 2013; 32:12471254.

115. Samame Perez-Vargas JC, Biondani P, Maggi C, Gariboldi M, Gloghini A, Inno A, Volpi CC, Gualeni AV, di Bartolomeo M, de Braud F, Castano A, Bossi I and Pietrantonio F. Role of cMET in the development and progression of colorectal cancer. Int J Mol Sci. 2013; 14:18056-18077.

116. Phan LM, Fuentes-Mattei E, Wu W, Velazquez-Torres G, Sircar K, Wood CG, Hai T, Jimenez C, Cote GJ, Ozsari L, Hofmann MC, Zheng S, Verhaak R, Pagliaro L, Cortez MA, Lee MH, et al. Hepatocyte Growth Factor/cMET Pathway Activation Enhances Cancer Hallmarks in Adrenocortical Carcinoma. Cancer Res. 2015; 75:4131-42.

117. Garzon R, Calin GA and Croce CM. MicroRNAs in Cancer. Annu Rev Med. 2009; 60:167-179.

118. Singh P, Soon PS, Feige JJ, Chabre O, Zhao JT, Cherradi N, Lalli E and Sidhu SB. Dysregulation of microRNAs in adrenocortical tumors. Mol Cell Endocrinol. 2012; 351:118128.

119. Igaz P, Igaz I, Nagy Z, Nyiro G, Szabo PM, Falus A, Patocs A and Racz K. MicroRNAs in adrenal tumors: relevance for pathogenesis, diagnosis, and therapy. Cell Mol Life Sci. 2015; 72:417-428.

120. Glover AR, Zhao JT, Gill AJ, Weiss J, Mugridge N, Kim E, Feeney AL, Ip JC, Reid G, Clarke S, Soon PS, Robinson BG, Brahmbhatt H, MacDiarmid JA and Sidhu SB. microRNA-7 as a tumor suppressor and novel therapeutic for adrenocortical carcinoma. Oncotarget. 2015; 6:3667536688. doi: 10.18632/oncotarget.5383.

121. Chabre O, Libe R, Assie G, Barreau O, Bertherat J, Bertagna X, Feige JJ and Cherradi N. Serum miR-483$5 \mathrm{p}$ and miR-195 are predictive of recurrence risk in 
adrenocortical cancer patients. Endocr Relat Cancer. 2013; 20:579-594.

122. Ortmann D, Hausmann J, Beuschlein F, Schmenger K, Stahl M, Geissler M and Reincke M. Steroidogenic acute regulatory (StAR)-directed immunotherapy protects against tumor growth of StAR-expressing Sp2-0 cells in a rodent adrenocortical carcinoma model. Endocrinology. 2004; 145:1760-1766.

123. Reincke M, Ortmann D, Hausmann J and Beuschlein F. Cytotoxic $\mathrm{T}$-cell response against steroidogenic acute regulatory protein using DNA vaccination followed by vaccinia virus infection in a mouse adrenal carcinoma model. Horm Metab Res. 2004; 36:411-414.

124. Zenkert S, Schubert B, Fassnacht M, Beuschlein F, Allolio $\mathrm{B}$ and Reincke M. Steroidogenic acute regulatory protein mRNA expression in adrenal tumours. Eur J Endocrinol. 2000; 142:294-299.

125. Liu J, Heikkila P, Kahri AI and Voutilainen R. Expression of the steroidogenic acute regulatory protein mRNA in adrenal tumors and cultured adrenal cells. J Endocrinol. 1996; 150:43-50.

126. Papewalis C, Fassnacht M, Willenberg HS, Domberg J, Fenk R, Rohr UP, Schinner S, Bornstein SR, Scherbaum WA and Schott M. Dendritic cells as potential adjuvant for immunotherapy in adrenocortical carcinoma. Clin Endocrinol (Oxf). 2006; 65:215-222.

127. Wolchok JD, Kluger H, Callahan MK, Postow MA, Rizvi NA, Lesokhin AM, Segal NH, Ariyan CE, Gordon RA, Reed K, Burke MM, Caldwell A, Kronenberg SA, Agunwamba BU, Zhang X, Lowy I, et al. Nivolumab plus ipilimumab in advanced melanoma. N Engl J Med. 2013; 369:122-133.

128. Brahmer J, Reckamp KL, Baas P, Crino L, Eberhardt WE, Poddubskaya E, Antonia S, Pluzanski A, Vokes EE, Holgado E, Waterhouse D, Ready N, Gainor J, Aren Frontera O, Havel L, Steins M, et al. Nivolumab versus Docetaxel in Advanced Squamous-Cell Non-Small-Cell Lung Cancer. N Engl J Med. 2015; 373:123-135.

129. Hodi FS, O'Day SJ, McDermott DF, Weber RW, Sosman JA, Haanen JB, Gonzalez R, Robert C, Schadendorf D, Hassel JC, Akerley W, van den Eertwegh AJ, Lutzky J, Lorigan P, Vaubel JM, Linette GP, et al. Improved survival with ipilimumab in patients with metastatic melanoma. $\mathrm{N}$ Engl J Med. 2010; 363:711-723.

130. Robert C, Long GV, Brady B, Dutriaux C, Maio M, Mortier L, Hassel JC, Rutkowski P, McNeil C, KalinkaWarzocha E, Savage KJ, Hernberg MM, Lebbe C, Charles J, Mihalcioiu C, Chiarion-Sileni V, et al. Nivolumab in previously untreated melanoma without BRAF mutation. $\mathrm{N}$ Engl J Med. 2015; 372:320-330.

131. Fay AP, Signoretti S, Callea M, Telomicron GH, McKay RR, Song J, Carvo I, Lampron ME, Kaymakcalan MD, Poli-de-Figueiredo CE, Bellmunt J, Hodi FS, Freeman GJ, Elfiky A and Choueiri TK. Programmed death ligand-1 expression in adrenocortical carcinoma: an exploratory biomarker study. J Immunother Cancer. 2015; 3:3.

132. Single Agent Pembrolizumab in Subjects With Advanced Adrenocortical Carcinoma ID NCT02673333. wwwclinicaltrialsgov. February 11th, 2016.

133. Study for the Evaluation of Efficacy of Pembrolizumab (MK-3475) in Patients With Rare Tumors. wwwclinicaltrialsgov. April, 12th 2016.

134. Nivolumab in Treating Patients With Metastatic Adrenocortical Cancer ID NCT02720484. wwwclinicaltrialsgov. April, 12th 2016.

135. Fichtner-Feigl S, Strober W, Kawakami K, Puri RK and Kitani A. IL-13 signaling through the IL-13alpha2 receptor is involved in induction of TGF-betal production and fibrosis. Nat Med. 2006; 12:99-106.

136. Jain M, Zhang L, He M, Patterson EE, Nilubol N, Fojo AT, Joshi B, Puri R and Kebebew E. Interleukin-13 receptor alpha2 is a novel therapeutic target for human adrenocortical carcinoma. Cancer. 2012; 118:5698-5708.

137. Liu-Chittenden Y, Jain M, Kumar P, Patel D, Aufforth R, Neychev V, Sadowski S, Gara SK, Joshi BH, CottleDelisle C, Merkel R, Yang L, Miettinen M, Puri RK and Kebebew E. Phase I trial of systemic intravenous infusion of interleukin-13-Pseudomonas exotoxin in patients with metastatic adrenocortical carcinoma. Cancer Med. 2015; 4:1060-1068.

138. Ross JS, Wang K, Rand JV, Gay L, Presta MJ, Sheehan CE, Ali SM, Elvin JA, Labrecque E, Hiemstra C, Buell J, Otto GA, Yelensky R, Lipson D, Morosini D, Chmielecki J, et al. Next-generation sequencing of adrenocortical carcinoma reveals new routes to targeted therapies. J Clin Pathol. 2014; 67:968-973.

139. Juhlin CC, Goh G, Healy JM, Fonseca AL, Scholl UI, Stenman A, Kunstman JW, Brown TC, Overton JD, Mane SM, Nelson-Williams C, Backdahl M, Suttorp AC, Haase M, Choi M, Schlessinger J, et al. Whole-exome sequencing characterizes the landscape of somatic mutations and copy number alterations in adrenocortical carcinoma. J Clin Endocrinol Metab. 2015; 100:E493-502.

140. de Reynies A, Assie G, Rickman DS, Tissier F, Groussin L, Rene-Corail F, Dousset B, Bertagna X, Clauser E and Bertherat J. Gene expression profiling reveals a new classification of adrenocortical tumors and identifies molecular predictors of malignancy and survival. J Clin Oncol. 2009; 27:1108-1115.

141. Giordano TJ, Thomas DG, Kuick R, Lizyness M, Misek DE, Smith AL, Sanders D, Aljundi RT, Gauger PG, Thompson NW, Taylor JM and Hanash SM. Distinct transcriptional profiles of adrenocortical tumors uncovered by DNA microarray analysis. Am J Pathol. 2003; 162:521531.

142. Slater EP, Diehl SM, Langer P, Samans B, Ramaswamy A, Zielke A and Bartsch DK. Analysis by cDNA microarrays of gene expression patterns of human adrenocortical tumors. Eur J Endocrinol. 2006; 154:587-598. 
143. Sidhu S, Marsh DJ, Theodosopoulos G, Philips J, Bambach CP, Campbell P, Magarey CJ, Russell CF, Schulte KM, Roher HD, Delbridge L and Robinson BG. Comparative genomic hybridization analysis of adrenocortical tumors. J Clin Endocrinol Metab. 2002; 87:3467-3474.

144. Velazquez-Fernandez D, Laurell C, Geli J, Hoog A, Odeberg J, Kjellman M, Lundeberg J, Hamberger B, Nilsson $\mathrm{P}$ and Backdahl M. Expression profiling of adrenocortical neoplasms suggests a molecular signature of malignancy. Surgery. 2005; 138:1087-1094.

145. Kjellman M, Kallioniemi OP, Karhu R, Hoog A, Farnebo LO, Auer G, Larsson C and Backdahl M. Genetic aberrations in adrenocortical tumors detected using comparative genomic hybridization correlate with tumor size and malignancy. Cancer Res. 1996; 56:4219-4223.

146. Poli G, Ceni E, Armignacco R, Ercolino T, Canu L, Baroni G, Nesi G, Galli A, Mannelli M and Luconi M. 2D-DIGE proteomic analysis identifies new potential therapeutic targets for adrenocortical carcinoma. Oncotarget. 2015; 6:5695-5706. doi: 10.18632/oncotarget.3299.
147. TCGA. The Cancer Genome Atlas (TCGA) program Data Portal Overview. https://tcga-datancinihgov/tcga/. 2016.

148. Stell A and Sinnott R. The ENSAT registry: a digital repository supporting adrenal cancer research. Stud Health Technol Inform. 2012; 178:207-212.

149. German adrenocortical carcinoma registry NCT00453674. wwwclinicaltrialsgov. February 11th, 2016.

150. Natural History and Tissue Acquisition Study of Adrenocortical Carcinoma NCT02015026. wwwclinicaltrialsgov. February 11th, 2016.

151. Kurzrock R and Giles FJ. Precision oncology for patients with advanced cancer: the challenges of malignant snowflakes. Cell Cycle. 2015; 14:2219-2221. 